\title{
Rubella in a returned traveller
}

\author{
Tiffany Chan MD, Derek R. MacFadden MD, Jerome A. Leis MD MSc
}

A 42-year-old previously healthy man, born in the Philippines, presented to the emergency department with fever and rash. Three days after returning from a twomonth visit to the Philippines where he had visited friends and family, the patient had sore throat, headaches and muscle pain. Four days later, a fever developed that lasted five days, and a red rash erupted over his trunk that spread to his arms, legs and face (Figure 1). At the same time that the rash developed, the patient experienced red and itchy eyes, runny nose and congestion, and joint pain distributed evenly on both sides of his body. The patient reported no pain behind the eyes, cough or abdominal symptoms.

Before travelling to the Philippines, the patient had not taken malaria prophylaxis or received any vaccinations. He reported that he had not undergone vaccination during his childhood in the Philippines because no routine vaccination programs were available at that time, and that he had not received any catch-up vaccination series in Canada. During his trip, the patient lived in rural areas and was exposed to farm animals; he did not report any sick contacts or new sexual partners.

On examination, the patient had pharyngeal erythema and enlarged tonsils without mucosal enanthem in addition to the rash on his trunk. There was no evidence of lymphadenopathy in the head and neck or hepatosplenomegaly. He had palpable joint effusions along the metacarpophalangeal joints bilaterally, with substantial warmth and stress tenderness.

Initial investigations were performed to rule out malaria, and blood cultures returned negative results. The patient was subsequently referred to our infectious diseases clinic. A throat swab had a negative result for group A streptococcus, and serologies for Dengue fever, parvovirus B19 and Chikungunya were negative. Owing to his lack of vaccinations, we ordered acute and convalescent serology for measles and rubella (one week apart). Measles immunoglobulin G ( $\mathrm{IgG}$ ) was present, likely secondary to natural immunity. An initial test for rubella immunoglobulin $\mathrm{M}$
(IgM) was positive, whereas IgG was nonreactive. One week later, the patient's IgM titre increased from 0.11 (cut-off $<0.8$ ) to $1.43 \mathrm{IU} /$ $\mathrm{mL}$, and IgG seroconverted to 140.06 (cut off $<8) \mathrm{IU} / \mathrm{mL}$, confirming acute infection. Rubella virus was detected in the patient's urine by reverse transcriptase polymerase chain reaction (PCR) testing, but a nasopharyngeal swab was negative. Rubella was diagnosed, and public health was notified.

Two weeks after presentation, the patient's fever and rash had resolved, and he had only mild residual joint tenderness in his hands. The patient's wife was confirmed not to be pregnant and was advised to undergo vaccination against measles, mumps and rubella (MMR), having not previously done so. There had been no contact with nonimmune pregnant women. The patient's son had previously received two doses of MMR vaccine and did not need to undergo additional vaccination.

\section{Discussion}

In Canada, a routine MMR vaccination program for infants was first started in April 1983, followed by a two-dose MMR program introduced across all provinces from 1996 to $1997 .{ }^{1}$ The advent of this program led to high rates of sustained immunity in the general population, with the mean number of rubella cases decreasing from about 4000 cases per year in 1979-1982, to fewer than 30 cases per year in 1998-2004. ${ }^{2}$ The

\section{KEY POINTS}

- Fever and rash are common complaints in the returned traveller, and should prompt health care workers to consider both vaccinepreventable and non-vaccine-preventable illnesses.

- Vaccine-preventable diseases may be more common in countries that do not have robust vaccination programs; health care workers should review vaccine status and offer catch-up vaccination series if necessary to immigrants and travellers.

- Rubella is a preventable illness; owing to the vaccine's efficacy, worldwide eradication is possible.

- Rubella is a reportable disease, and contact tracing should be done with the involvement of public health for exposed individuals, particularly pregnant women. 
most recent outbreak in Canada occurred in 2005, when more than 300 cases were reported in southwestern Ontario ${ }^{2}$ that were attributed to suboptimal immunity in communities that opposed vaccination. Between 2006 and 2011, there were fewer than 13 cases per year, ${ }^{2}$ with only two reported cases in 2012.

As of April 2015, the transmission of rubella has been declared eliminated across the World Health Organization regions of the Americas, but outbreaks are an ongoing concern in areas missed or not yet targeted by rubella vaccination programs. ${ }^{3}$ In the Philippines, a measles outbreak in 2011 sparked a two-month measlesrubella supplementary vaccination program that targeted $84 \%$ of children. However, despite a more recent outbreak in 2014 , introduction of a permanent national routine vaccination program in the Philippines has yet to begin. ${ }^{4}$

\section{Clinical features}

Rubella, also called German measles, is caused by an RNA virus of the Togaviridae family. It is transmitted through droplet or direct contact of nasopharyngeal secretions of people who are infected, or through maternal-fetal transplacental transmission during pregnancy. The incuba- tion period is 14-23 days, and patients are considered to be contagious one week before and for at least four days after the onset of rash. ${ }^{2,5}$

Our patient presented with typical clinical features of rubella, including a prodrome of fever one to five days before the onset of the rash. The exanthem is characterized by pinpoint pink macules and papules that appear over the face and spread cephalocaudally over the trunk and extremities within 24 hours. It lasts a median of three days but quickly fades in the same manner. As seen in our patient's case, the rash is associated with coryza, nonexudative conjunctivitis, arthralgia and symmetric small joint arthritis. ${ }^{2,5}$ Our patient did not, however, have the typical posterior auricular and suboccipital lymphadenopathy. Overall, patients have mild symptoms and some are even asymptomatic, although adults tend to have more symptoms with longer duration than are seen in children.

\section{Diagnosis}

Fever and rash in a returned traveller is a nonspecific but common complaint that includes a wide differential diagnosis (Box 1). An essential diagnosis to exclude in our patient's case was malaria, which typically does not cause a rash
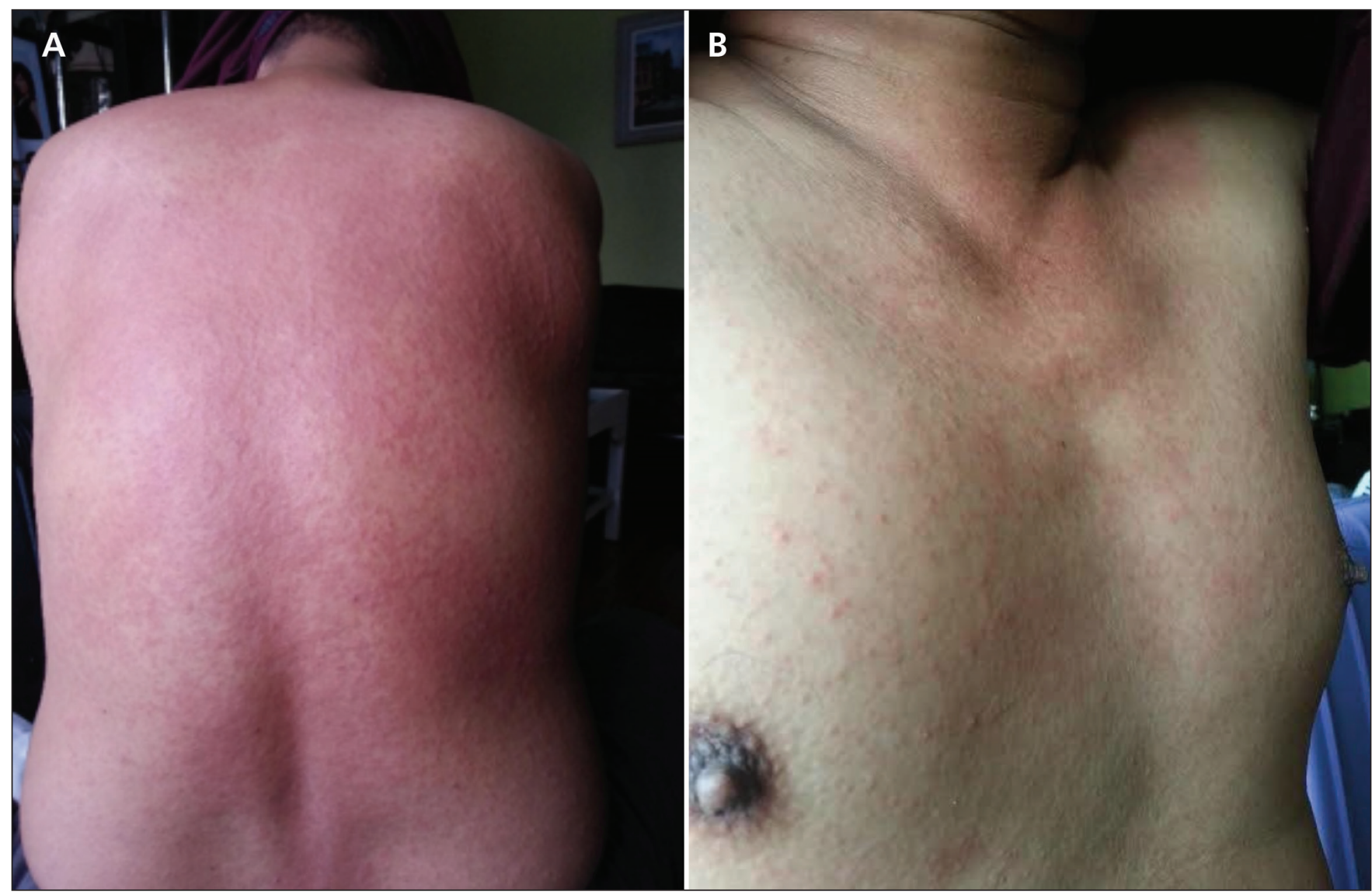

Figure 1: Diffuse erythematous maculopapular rash extending over the back (A) and anterior chest wall (B) of a 42-year-old man recently returned from the Philippines. Rubella was diagnosed. 
except in severe cases owing to coagulopathy. Scarlet fever was considered owing to our patient's pharyngitis, as were parvovirus B19, Chikungunya and rubella as acute viral causes for his arthritis. Considering our patient's lack of vaccination, both rubella and measles were important vaccine-preventable diseases to rule out, although the latter is more often associated with conjunctivitis.

The diagnosis of rubella is usually made by serology, but the timing of testing in the patient's presentation should be considered in the interpretation of the results. The detection of rubellaspecific IgM in serum is only $50 \%$ sensitive at the onset of rash. ${ }^{9}$ Most patients will have a detectable IgM titre four days after the onset of rash, which remains detectable for six to eight weeks. ${ }^{9}$ This was evident in our patient's case; his serum IgM level was above the cut-off level only after repeat testing. In Canada, reverse transcriptase PCR testing can be done using nasopharyngeal and urine specimens. Such tests can detect virus at the onset of rash and return positive results for up to 10 days. ${ }^{9}$

\section{Management and prevention}

Symptoms of rubella resolve spontaneously, and no specific treatment is required. A greater focus remains on preventing transmission to pregnant women because of the risk of congenital rubella syndrome. In Canada, recommendations for routine vaccination for rubella are with a single dose of MMR vaccine at $12-15$ months of age..$^{10}$ One dose of vaccine has been shown to produce a seroconversion rate of about $95 \% .^{5}$ Pregnancy, anaphylaxis and immunocompromised status are contraindications to the vaccine, and pregnancy should be avoided for one month after undergoing vaccination.

One of the challenges to prevention is verifying immunization status among immigrants who may have inadequate or no vaccination records. Review of immunization status and routine serologic testing to determine immunity of children and adults without vaccination records is not standard practice for preimmigration medical assessment in Canada. People lacking adequate vaccination documentation, including our patient, should be considered nonimmune and

\begin{tabular}{|c|c|c|c|c|}
\hline Disease & Pathogen & Rash & Clinical features & Diagnosis \\
\hline Malaria & Plasmodium species & $\begin{array}{l}\text { Uncommon; petechial } \\
\text { hemorrhage may be } \\
\text { seen in severe cases }\end{array}$ & $\begin{array}{l}\text { Cyclic fever, headaches, } \\
\text { myalgias }\end{array}$ & $\begin{array}{l}\text { Thick and thin blood } \\
\text { smears; rapid antigen } \\
\text { test }\end{array}$ \\
\hline Dengue fever & Flavivirus & $\begin{array}{l}\text { Maculopapular rash } \\
\text { over the trunk with } \\
\text { sparing of the palms } \\
\text { and soles }\end{array}$ & $\begin{array}{l}\text { Fever, retro-orbital pain, } \\
\text { severe myalgia ("break- } \\
\text { bone fever") }\end{array}$ & Serology \\
\hline Chikungunya fever & Chikungunya virus & $\begin{array}{l}\text { Maculopapular rash } \\
\text { with discrete areas of } \\
\text { sparing }\end{array}$ & $\begin{array}{l}\text { Fever, headache, severe } \\
\text { arthralgia and arthritis }\end{array}$ & Serology \\
\hline $\begin{array}{l}\text { Infectious } \\
\text { mononucleosis }\end{array}$ & Epstein-Barr virus & $\begin{array}{l}\text { Maculopapular urticarial } \\
\text { rash associated with } \\
\text { antibiotic use }\end{array}$ & $\begin{array}{l}\text { Fever, pharyngitis, } \\
\text { lymphadenopathy, } \\
\text { hepatitis }\end{array}$ & Monospot test; serology \\
\hline Scarlet fever & $\begin{array}{l}\beta \text {-hemolytic } \\
\text { Streptococcus pyogenes }\end{array}$ & $\begin{array}{l}\text { "Sandpaper-like rash" } \\
\text { on the trunk, spreading } \\
\text { to the extremities }\end{array}$ & $\begin{array}{l}\text { Fever, headache, } \\
\text { exudative pharyngitis, } \\
\text { cervical } \\
\text { lymphadenopathy, } \\
\text { strawberry tongue }\end{array}$ & $\begin{array}{l}\text { Throat culture; rapid } \\
\text { antigen test; } \\
\text { antistreptolysin O titres }\end{array}$ \\
\hline $\begin{array}{l}\text { Erythema } \\
\text { infectiosum }\end{array}$ & Parvovirus B19 & $\begin{array}{l}\text { "Slapped-cheek" rash } \\
\text { progressing to lacy } \\
\text { reticular rash over the } \\
\text { trunk and extremities }\end{array}$ & $\begin{array}{l}\text { Fever, headache, coryza, } \\
\text { arthritis, arthralgia }\end{array}$ & Serology \\
\hline Rubeola (measles) & Measles virus & $\begin{array}{l}\text { Maculopapular rash } \\
\text { beginning on the face } \\
\text { and neck, spreading } \\
\text { centrifugally }\end{array}$ & $\begin{array}{l}\text { Fever, coryza, } \\
\text { conjunctivitis, Koplik } \\
\text { spots }\end{array}$ & Serology \\
\hline Rubella & Rubella virus & $\begin{array}{l}\text { Pink maculopapular rash } \\
\text { beginning on the } \\
\text { forehead, then } \\
\text { spreading over the } \\
\text { trunk }\end{array}$ & $\begin{array}{l}\text { Fever, } \\
\text { lymphadenopathy, } \\
\text { arthralgias, arthritis, } \\
\text { petechiae on the palate }\end{array}$ & Serology \\
\hline
\end{tabular}


start on a vaccine schedule appropriate for their age and risk factors. ${ }^{11} \mathrm{Had}$ our patient undergone vaccination while living in Canada, his illness could have been prevented.

Rubella is a notifiable disease in Canada, and reporting confirmed cases to local public health units is mandatory. Patients should be excluded from work (including health care settings), school or child care for seven days after the onset of rash. ${ }^{12}$ If patients are pregnant or have contact with pregnant women, the respective maternity care provider should be notified to assess and report the susceptibility of the pregnant woman to rubella and the outcome of the pregnancy. ${ }^{12}$ The MMR vaccine should be offered to all other susceptible nonpregnant contacts. $^{12}$

\section{Conclusion}

Although routine childhood vaccination with MMR has existed in Canada for decades, rubella vaccine coverage varies among countries that lack childhood vaccination programs. The key to making the diagnosis in our patient was eliciting that he had never undergone vaccination during childhood. Our patient's case reinforces the need to ensure that the immunization status of all new immigrants to Canada is assessed and that vaccination is offered accordingly.

\section{References}

1. Macey JF, Tam T, Lipskie T, et al. Rubella elimination, the Canadian experience. J Infect Dis 2011;204:S585-92.

2. Rubella. Ottawa: Public Health Agency of Canada; 2013. Available: www.phac-aspc.gc.ca/im/vpd-mev/rubella-eng.php (accessed 2015 Apr. 6).

3. Americas region is declared the world's first to eliminate rubella. Geneva: Pan American Health Organization/World Health Organization; 2015. Available: www.paho.org/hq/index.php ?option=com_content\&view=article $\&$ id $=10798 \% 3$ Aamericas-free -of-rubella\&Itemid=1926\&lang=en (accessed 2015 Aug. 8).
4. Rubella and congenital rubella syndrome (CRS). Geneva: World Health Organization: Western Pacific Region; 2012. Available: www.wpro.who.int/mediacentre/factsheets/fs 20120228/en/ (accessed 2015 July 26).

5. Best JM. Rubella. Semin Fetal Neonatal Med 2007;12:182-92.

6. O'Brien BM. A practical approach to common skin problems in returning travelers. Travel Med Infect Dis 2009;7:125-46.

7. Looke DF, Robson JM. Infections in the returned traveler. Med J Aust 2002;177:212-9.

8. McKinnon HD, Howard T. Evaluating the febrile patient with a rash. Am Fam Physician 2000;62:804-16.

9. Lambert N, Strebel P, Orenstein W, et al. Rubella. Lancet 2015; 1-11.

10. Rubella (German measles, three-day measles). Atlanta: Centers for Disease Control and Prevention; 2014. Available: www.cdc. gov/rubella/about/index.html (accessed 2015 Apr. 6).

11. Canadian immunization guide: part 3. Vaccination of specific populations. Ottawa: Public Health Agency of Canada; 2013. Available: www.phac-aspc.gc.ca/publicat/cig-gci/p03-11-eng. php (accessed 2015 Aug. 8).

12. Appendix A: Disease specific chapters. Rubella. Toronto: Ontario Ministry of Health and Long-Term Care; 2013. Available: www.health.gov.on.ca/en/pro/programs/publichealth/oph standards/docs/rubella_chapter.pdf (accessed 2015 Apr. 6).

Affiliations: Department of Medicine (Chan, MacFadden, Leis), University of Toronto; Division of Infectious Diseases (MacFadden, Leis), Sunnybrook Health Sciences Centre; and Centre for Quality Improvement and Patient Safety (Leis), University of Toronto, Toronto, Ont.

Contributors: All authors had access to the data and contributed to the preparation of this manuscript. All of the authors approved the final version to be published and agree to act as guarantors of the work.

The section Cases presents brief case reports that convey clear, practical lessons. Preference is given to common presentations of important rare conditions, and important unusual presentations of common problems. Articles start with a case presentation (500 words maximum), and a discussion of the underlying condition follows (1000 words maximum). Visual elements (e.g., tables of the differential diagnosis, clinical features or diagnostic approach) are encouraged. Consent from patients for publication of their story is a necessity. See information for authors at www.cmaj.ca. 